\title{
Energy Audit Methodology of Sponge Iron Manufacturing Units Using DRI Process
}

\author{
Avijit Choudhury \\ Enfragy Solutions, New Delhi, India \\ Email: avijit.choudhury@enfragy.com
}

Received 14 July 2014; revised 10 August 2014; accepted 18 August 2014

Copyright (C) 2014 by author and Scientific Research Publishing Inc.

This work is licensed under the Creative Commons Attribution International License (CC BY). http://creativecommons.org/licenses/by/4.0/

(c) (i) Open Access

\begin{abstract}
Conducting complete energy audit (both process and utility) of a sponge iron unit is challenging as there is no laid down procedure to audit the process side. Further, the average heat to power ratio $\left(\mathrm{kW}_{\mathrm{th}} / \mathrm{kW}_{\mathrm{e}}\right)$ of sponge iron plants ranges from (25:1) to (31:1). This shows that the manufacturing process mostly uses thermal energy and application of electrical energy is insignificant. The main $\&$ only source of thermal energy is coal and the entire coal is fed to the rotary kiln. Therefore we find that "Kiln" is the "Black-Box" of this industry and the success of energy efficiency is hidden in the kiln process chemistry. This article tries to establish detailed energy audit methodology of sponge iron manufacturing process or kiln operation with a view to finding out major energy saving potential of the unit. In the research work we find that it is the incomplete reaction of coal that causes the major energy inefficiency in the process. Substantial amount of un-reacted carbon comes out with the char (by-product) which has virtually zero commercial value. The article also puts a question mark on the justification of using high-grade imported coal in such energy inefficient industries.
\end{abstract}

\section{Keywords}

Energy Audit, DRI Process, Sponge Iron, Kiln Efficiency, Sankey Diagram of Kiln, Coal Balancing

\section{Background of This Study}

Sponge iron industries in India have mandatory energy performance target in terms of specific energy consumption (SEC). They shall have to achieve the target SEC by $31^{\text {st }}$ March, 2015. The non-performing industries are required to pay heavy penalty for the excess amount of energy consumed (toe). On the contrary, the performing industries shall be rewarded by the issuance of energy-saving certificates. Hence apart from commercial aspects, energy performance has big legal implication as well. 


\section{Description of Sponge Iron Manufacturing Process}

Most of the plants in India use DRI process-a solid state direct reduction process by which iron ore is reduced to sponge without phase change (Figure 1). Raw material mix-iron ore, dolomite and coal are fed to one end of rotary Kiln and product sponge iron along with char is taken out from the other end. Apart from this, primary and secondary airs are supplied to the Kiln to initiate the combustion and reaction processes. The reaction takes place at high temp $\left(1050^{\circ} \mathrm{C}\right.$ to $\left.1065^{\circ} \mathrm{C}\right)$. Coal plays a dual role in the Kiln. Part of coal is used as fuel to supply the desired heat so as to take the raw materials to the desired temp. But main role of coal is to supply carbon in the reduction process. Dolomite is used as sulphur scavenger which finally comes out with the char. Char contains ash of coal and other impurities of iron ore. The reactions inside the kiln are given below [1]:

$$
\begin{gathered}
\mathrm{C}+\mathrm{O}_{2}=\mathrm{CO}_{2} \\
\mathrm{CO}_{2}+\mathrm{C}=2 \mathrm{CO} \\
3 \mathrm{Fe}_{2} \mathrm{O}_{3}+\mathrm{CO}=2 \mathrm{Fe}_{3} \mathrm{O}_{4}+\mathrm{CO}_{2} \\
\mathrm{Fe}_{3} \mathrm{O}_{4}+\mathrm{CO}=3 \mathrm{FeO}+\mathrm{CO}_{2} \\
\mathrm{FeO}+\mathrm{CO}=\mathrm{Fe} \text { (product) }+\mathrm{CO}_{2}
\end{gathered}
$$

Plants in India use wide variety of raw material and coal which has direct bearing on the process. Again some plants don't use iron ore directly. They make iron pellets before feeding it to rotary kiln. For this reason we will consider the data of one specific plant in our approach rather than taking a generalized view.

Few highlighting points of the selected plant are given below to understand the process better:

- Other than oxides of Fe, iron ore also contains impurities like gangue material, sulphur, phosphorous and moisture. The quality of ore is determined by the iron percentage as it has direct bearing on the yield. The best quality feed has the following characteristics (Table 1).

- As mentioned earlier Dolomite is used here as sulphur scavenger-it doesn't have any role in the main stoichiometric reaction. Dolomite typically contains $\mathrm{MgO}(20 \%), \mathrm{CaO}(28 \%)$ and acid soluble (7\%). The size of dolomite is 2 - $8 \mathrm{~mm}$ hence no crushing is required.

- The reducing agent is here non-coking coal. Coal size is $20 \mathrm{~mm}+$ hence it requires crushing before feeding into kiln. The plant is using two different grades of coal (Table 2), both are of high quality. Coals are mixed

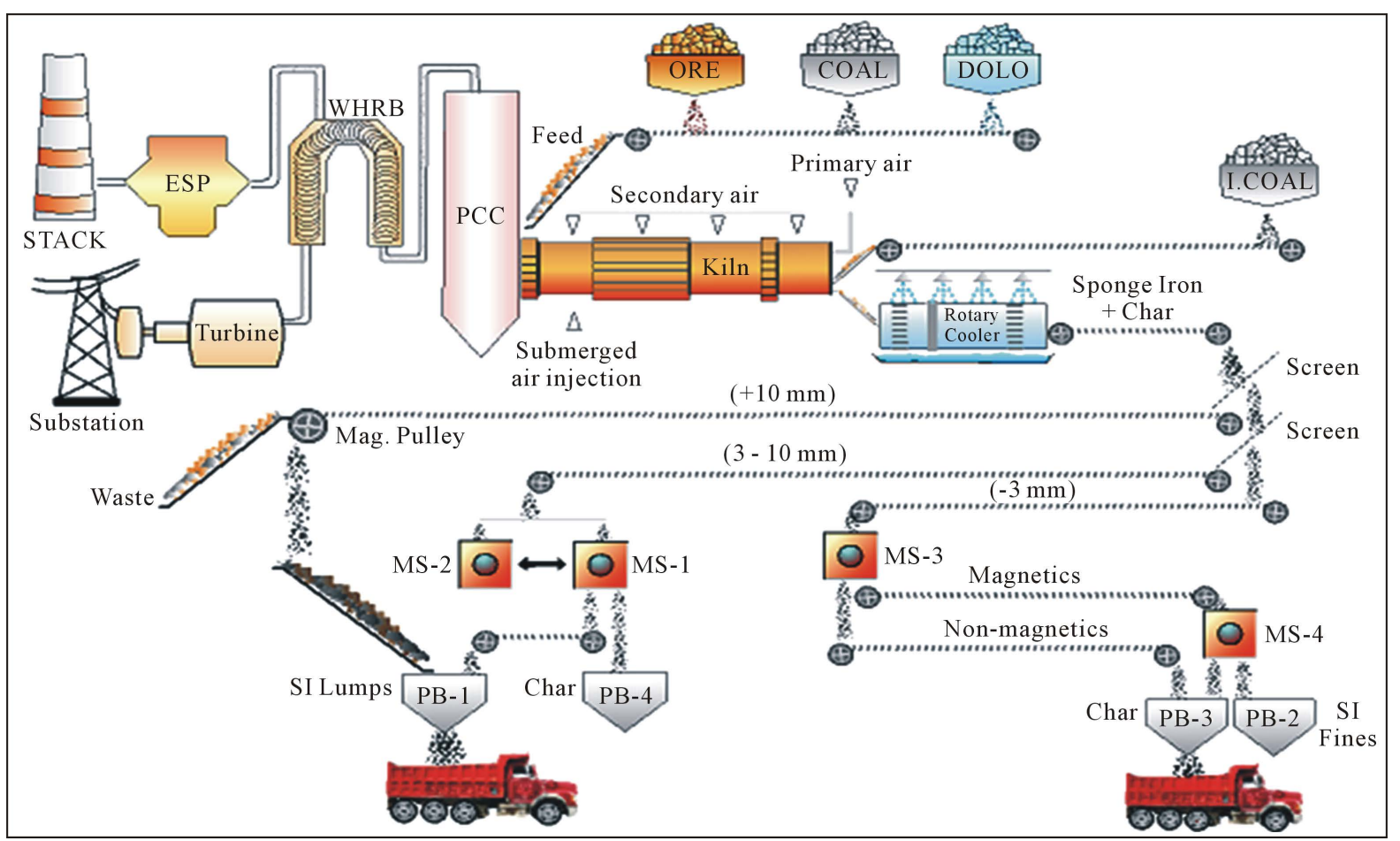

Figure 1. Process flow diagram of the plant under discussion. 
Table 1. Composition of raw material fed to the kiln.

\begin{tabular}{|c|c|c|}
\hline \multicolumn{3}{|c|}{$\mathrm{SiO}_{2}+\mathrm{Al}_{2} \mathrm{O}_{3}$ (Gangue material): $5 \%$} \\
\hline \multicolumn{3}{|c|}{ Sulphur: $0.01 \%$} \\
\hline \multicolumn{3}{|c|}{ Phosphorous: $0.05 \%$} \\
\hline \multicolumn{3}{|c|}{ Moisture: $1 \%$} \\
\hline \multicolumn{3}{|c|}{ Size: 3 - $18 \mathrm{~mm}$ (no crushing required, can be fed to kiln directly) } \\
\hline able 2. Composit & coal fed the & \\
\hline Coal Properties & Indian Coal & South African Coal \\
\hline Fixed Carbon \% & 43 & 55 \\
\hline Volatile matter \% & 31 & 30 \\
\hline Moisture \% & 12 & 9 \\
\hline Ash \% & 26 & 15 \\
\hline GCV (Kcal/Kg) & 5360 & 6540 \\
\hline
\end{tabular}

approximately in 50:50 ratio before feeding to the kiln [1].

- Because of the huge length of the kiln and to maintain the temperature profile, $40 \%$ coal is injected from the discharge end.

- Sponge iron produced by this plant is of high grade which contains $80 \% \mathrm{Fe}, 12 \% \mathrm{FeO}$ and $8 \%$ gangue material. After separation of sponge iron in the magnetic screen/pulley, the remains are collected as char. Char has good amount of fixed carbon (28\% - 35\%) and moderate GCV $(2720-2780 \mathrm{Kcal} / \mathrm{Kg})$. Char is sold outside as low grade fuel which is subsequently used in brick kiln or large boiler. Out of the total kiln discharge, $15 \%$ to $20 \%$ is the char generation.

\section{Main Challenges for the Energy Auditors}

- There is no benchmark data available of kiln efficiency in sponge iron unit.

- As per Indian accounting methodology (gate-to-gate concept), the only input energy is coal. Because electricity is produced from the kiln's waste heat and it is more than sufficient to take care of the entire electrical load of the plant.

- Again coal performs dual functions inside the kiln. Major part is used as raw material in the process—as reducing agent. Remaining part is used as fuel.

- So how to bifurcate the amount of coal as reducing agent vis-a-vis as fuel?

- There are numerous reactions inside the kiln. Whether the overall reaction is exothermic or endothermic?

- What is the amount of heat released or absorbed in the reactions that need to be considered for calculating the net heat demand of the process?

As long as these replies are unknown to energy auditor, he can't do the mass and heat balance of the kiln which is pre-requisite to determine the kiln efficiency.

\section{Purpose of Work}

The main purpose of this work is:

1) To suggest a change in the existing accounting methodology that considers the entire coal as fuel. However the process chemistry suggests that the overall reaction is exothermic and theoretically no fuel is required once the reaction has started. Only fuel requirement is to supply the start-up heat to take the reactants to the desired temp level.

2) To suggest a new methodology to define and measure the Kiln thermal efficiency. 


\section{Controlling Parameters}

As far as energy consumption is concerned, there is only one major parameter-coal consumption. The amount of electrical energy consumed by the kiln auxiliaries like motor of the kiln rotating drives, air blowers etc. is insignificant compared to coal consumption. Therefore the coal charging should be optimized so that minimum coal comes out from the kiln along with char. Similarly air supply (Figure 2) should be such that there is minimum $\mathrm{O}_{2}$ level in the flue gas. In other words, air supply should not be in excess than the stoichiometric requirement so that heat loss thru flue gas is minimum.

\section{Methodology}

In the methodology:

1) We need to assume ideal condition first and find out what is the theoretical mass \& heat balance of the kiln and its specific energy requirement.

2) Once the above is established then we will find the actual heat \& mass balance along with actual SEC taking the operating data from the plant.

3) Comparison of actual SEC vs. theoretical SEC shall give the kiln efficiency.

Now consider an ideal situation where:

- Iron ore contains $100 \% \mathrm{FeO}-\mathrm{no} \mathrm{Fe}_{3} \mathrm{O}_{4}$ and other impurities.

- Theoretically no dolomite is required as there is no impurity.

- Char contains only the ash of coal (no dolomite, no un-reacted carbon \& other impurities).

- Only one grade of coal is used hence coal property is the average of imported \& indigenous coal. Thus average coal properties become:

Fixed carbon $=50 \%$ (by wt)

Volatile matter $=30 \%$ (by wt)

Moisture $=10 \%$ (by wt)

Ash $=10 \%$ (by wt)

Avg GCV $=5950 \mathrm{Kcal} / \mathrm{Kg}$

- Volatile matter contains only methane $\left(\mathrm{CH}_{4}\right)$.

- Since VM is released at much lower temp (around $300^{\circ} \mathrm{C}$ ), it doesn't take part in the main reduction reaction-burns out completely and generates heat.

- Reduction reaction is $100 \%$ complete and final product doesn't content any $\mathrm{FeO}$ or impurity.

Considering the above ideal situations and balancing the chemical equations we get:

$$
\begin{gathered}
3 \mathrm{C}(36)+3 \mathrm{O}_{2}(96)=3 \mathrm{CO}_{2}(132) \\
3 \mathrm{CO}_{2}(132)+3 \mathrm{C}(36)=6 \mathrm{CO}(168) \\
\text { Rotary Kiln Cross-section }
\end{gathered}
$$

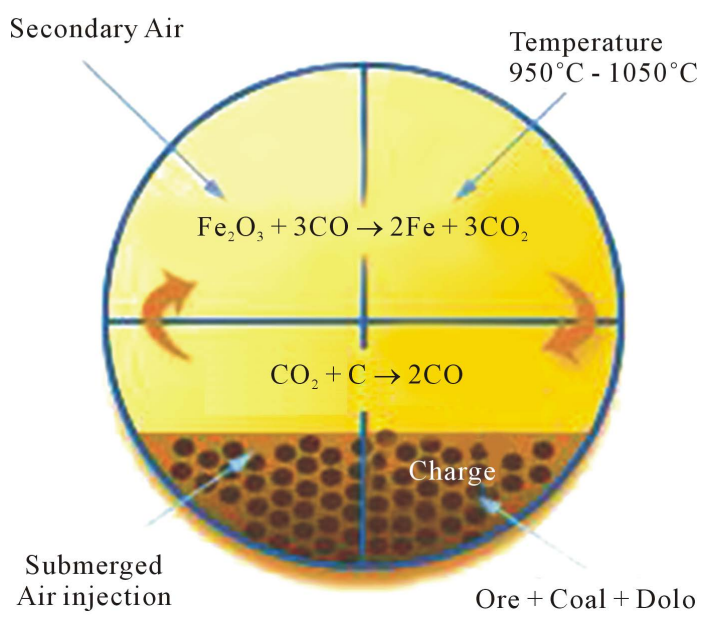

Figure 2. Cross-section of kiln. 


$$
2 \mathrm{Fe}_{2} \mathrm{O}_{3}(320)+6 \mathrm{CO}(168)=4 \mathrm{Fe}(224)+6 \mathrm{CO}_{2}(264)[2] .
$$

The figures in the bracket indicate the weight of the reactants and products. From the above equations we get $72 \mathrm{Kg}$ carbon or $144 \mathrm{Kg}$ coal $+96 \mathrm{Kg} \mathrm{O}$ or $417 \mathrm{Kg}$ air $+320 \mathrm{Kg}$ ore reacts to generate $224 \mathrm{Kg}$ of sponge iron \& $264 \mathrm{Kg}$ of $\mathrm{CO}_{2}$. Or in other words, to produce $1 \mathrm{Kg}$ of pure sponge iron the stoichiometric requirements of reagents are:

$$
\begin{gathered}
\text { Iron ore }(\text { pure })=1.43 \mathrm{Kg} \\
\text { Coal }=0.64 \mathrm{Kg} \& \text { Air }=1.86 \mathrm{Kg}
\end{gathered}
$$

The products are:

$$
\begin{gathered}
\mathrm{CO}_{2}=1.18 \mathrm{Kg} \\
\text { Flue gas generated }=2.86 \mathrm{Kg} \\
\text { Char (ash of coal taken) }=0.064 \mathrm{Kg}
\end{gathered}
$$

In the above only the fixed carbon of coal has been considered and volatile matter has been left out. Burning of volatile matter shall require additional air:

$$
\mathrm{CH}_{4}+2 \mathrm{O}_{2}=\mathrm{CO}_{2}+2 \mathrm{H}_{2} \mathrm{O}
$$

The stoichiometric requirement of air to burn one Kg-mole of methane (16 Kg of methane) is $278.26 \mathrm{Kg}$. Here amount of coal is $0.64 \mathrm{Kg}$ and $\mathrm{CH}_{4}$ present in this coal is $0.192 \mathrm{Kg}$ ( $30 \%$ by wt). Hence additional air requirement on account of $\mathrm{CH}_{4}$ is $=3.34 \mathrm{Kg}$

Thus the final stoichiometric ratio becomes:

$$
\text { Ore:Coal:Air:Sponge:Flue:Char = 1.43:0.64:5.20:1:6.20:0.064 }
$$

If no excess air is given in the kiln then flue gas will not have any $\mathrm{O}_{2}$ and $\mathrm{CO}$ (Ideal condition).

\section{Calculation of Heat of Reaction}

Now let us see the heat implication of various reactions that are taking place in the kiln. Chemical reactions are either exothermic or endothermic in nature. It is really cumbersome and difficult to find out the heat of reaction $(\Delta \mathrm{Hr})$ of individual equation. That's why we need to apply "Hess's Law of Constant Heat Summation" which states that "For a given chemical process the net heat change will be same whether the process occurs in one or several stages" [3].

Adding all the basic reactions, we get the final reaction as below:

$$
2 \mathrm{Fe}_{2} \mathrm{O}_{3}+6 \mathrm{C}+3 \mathrm{O}_{2}=4 \mathrm{Fe}+6 \mathrm{CO}_{2}+\Delta \mathrm{Hr}-\text { Final Reaction }
$$

Standard Heat of Formation of $\mathrm{Fe}_{2} \mathrm{O}_{3} \& \mathrm{CO}_{2}$ are -825.5 \& $-393.5 \mathrm{KJ} /$ mole respectively. Heat of formation of elements is taken zero. Now taking the final reaction $\&$ applying thermodynamic principal we can write:

$$
\Delta \mathrm{Hr}=\sum \Delta \mathrm{H}_{\text {products }}-\sum \Delta \mathrm{H}_{\text {reactants }}[4],
$$

Or, $\Delta \mathrm{Hr}=6(-94,139)-2 \times(-197,488)$

[Heat of formation values converted into $\mathrm{Kcal} / \mathrm{Kg}$-mole]

Or, $\Delta \mathrm{Hr}=-169,856 \mathrm{Kcal}$ (overall reaction)

Or, $\Delta \mathrm{Hr}=-758.28 \mathrm{Kcal}$ per $\mathrm{Kg}$ of $\mathrm{Fe}$

Since $\Delta \mathrm{Hr}$ is negative the overall reduction reaction in the kiln is exothermic. So when $1 \mathrm{Kg}$ of sponge iron is produced $758 \mathrm{Kcal}$ of heat is evolved.

In the above reaction we have considered only Carbon of coal. Again some heat is gained by the burning of volatile matter. From $1 \mathrm{Kg}$ coal contribution of VM is $5950-3919=2031 \mathrm{Kcal}$. Hence for $0.64 \mathrm{Kg}$ coal heat contribution of VM is $1300 \mathrm{Kcal}$. Therefore total heat gain or available heat is $758+1300=2058 \mathrm{Kcal}$.

Now let us see what the heat loss areas are:

Since the reaction occurs between $1050^{\circ} \mathrm{C}$ to $1065^{\circ} \mathrm{C}$, some amount of sensible heat is also required to preheat the charged material. Also the hot products coming out of the kiln carry substantial amount of sensible heat. Taking reaction temp as $1065^{\circ} \mathrm{C}$ and ambient temp $20^{\circ} \mathrm{C}$ :

- Sensible heat of Sponge iron $(1 \mathrm{Kg})=124.35 \mathrm{Kcal}$ (specific heat 0.119$)$.

- Sensible heat of char $(0.064 \mathrm{Kg})=13.24 \mathrm{Kcal}$ (specific heat 0.198). 
- Sensible heat of flue $(6.2 \mathrm{Kg})=1554.96 \mathrm{Kcal}$ (specific heat 0.24$)$.

- Total sensible heat load at $1065^{\circ} \mathrm{C}=1692.55 \mathrm{Kcal}$.

- Now coal is having $10 \%$ moisture. Heat loss on account of moisture $=65.46 \mathrm{Kcal}$.

- Considering $30 \% \mathrm{VM}^{2}$ and $\mathrm{CH}_{4}$ is its constituent, Hydrogen content of coal is 7.5\%.

- Heat loss on account of vapour formation from hydrogen $=49.09 \mathrm{Kcal}$.

- Net heat demand to complete the reaction $=1807.10 \mathrm{Kcal}$.

- Net excess heat in the reaction $=2058.12-1807.10=251.02 \mathrm{Kcal}$.

\section{Results}

\subsection{Theoretical Mass Balance, Ideal Case}

Let us now see the amount of iron ore (pure) and coal (of the given property) need to be charged in the kiln to produce $1 \mathrm{Kg}$ of pure sponge iron (Table 3 ).

\subsection{Interpretations}

Therefore it is observed that:

1) The overall iron reduction reaction is exothermic. $2058 \mathrm{Kcal}$ heat is evolved when $1 \mathrm{Kg}$ of pure sponge iron is produced.

2) There are some unavoidable losses like-sensible heat losses thru hot products \& flue gas + loss on account of moisture \& hydrogen present in the coal. All these loss put together is $1807 \mathrm{Kcal}$.

3) After discounting all losses, still there is net gain of 251 Kcal (12.19\% of the supplied heat).

4) Thus it is established that theoretically no extra coal is required as fuel other than the stoichiometric requirement (which is required as reducing agent).

\subsection{Theoretical Heat Balance, Ideal Case (Table 4)}

Negative sign indicates exothermic reaction or heat release and positive sign indicates requirement or absorption of heat.

Table 3. Mass balance of reactants \& products to produce $1 \mathrm{Kg}$ of pure sponge iron.

\begin{tabular}{cccc}
\hline Iron Ore & $1.43 \mathrm{Kg}$ & Heat Supplied $=2058 \mathrm{Kcal}$ & Sponge Iron \\
Coal & $0.64 \mathrm{Kg}$ & $-251 \mathrm{Kcal}$ (Excess Heat) & Char \\
Air & $5.20 \mathrm{Kg}$ & Flue Gas & $6.064 \mathrm{Kg}$ \\
Total Input & $7.270 \mathrm{Kg}$ & Total Output & $7.264 \mathrm{Kg}$ \\
\hline
\end{tabular}

Table 4. Heat balance of ideal kiln ( $100 \%$ coal used as reducing agent \& no coal is used as fuel).

\begin{tabular}{cc} 
Component & Heat Value (Kcal) \\
\hline Sponge iron sensible heat; assuming $\Delta \mathrm{t}=1045^{\circ} \mathrm{C}$ & +124 \\
Char sensible heat; assuming $\Delta \mathrm{t}=1045^{\circ} \mathrm{C}$ & +13 \\
Flue gas sensible heat; assuming $\Delta \mathrm{t}=1045^{\circ} \mathrm{C}$ & +1555 \\
Heat loss due to moisture present in the coal & +66 \\
Heat loss due to vapor formed from hydrogen of coal & +49 \\
Heat of iron reduction reaction (exothermic) & -758 \\
Heat gain from burning of VM of coal & -1300 \\
Net heat surplus in overall Kiln reaction & -251 \\
Total additional heat/coal requirement to produce 1 Kg sponge iron & nil \\
\hline
\end{tabular}




\subsection{Sankey Diagram}

The heat balancing of ideal kiln is given below (Figure 3).

\section{Actual Case Production Data}

Now let us take the actual production data of the kiln collected from the plant. The averages of three consecutive day's value are given below [1]:

- Coal $=13.17 \mathrm{tph}$

- Iron ore $=21.53 \mathrm{tph}$

- Dolomite $=0.958$ tph

- Air $=45.60$ tph

- $\quad$ Sponge Iron = 13.9 tph

- Length and diameter of kiln are $72 \& 3.74$ meters respectively

- Inside temp of kiln $=1065^{\circ} \mathrm{C}$

- Surface temp of kiln $=268^{\circ} \mathrm{C}$

- The char contents high \% of fixed carbon and its GCV is $2749.5 \mathrm{Kcal} / \mathrm{Kg}$

\section{Actual Mass Balance of Kiln (Basis $1 \mathrm{Kg}$ Sponge Iron)}

Mass balance done with plant production data is given below in (Table 5). Please note that plant usually doesn’t $\log$ their daily char production data as it has insignificant commercial value. Hence amount of char production is calculated from the impurity figures. Similarly flue gas data recorded by the plant was found incorrect hence correct figure was calculated from the air charging data.

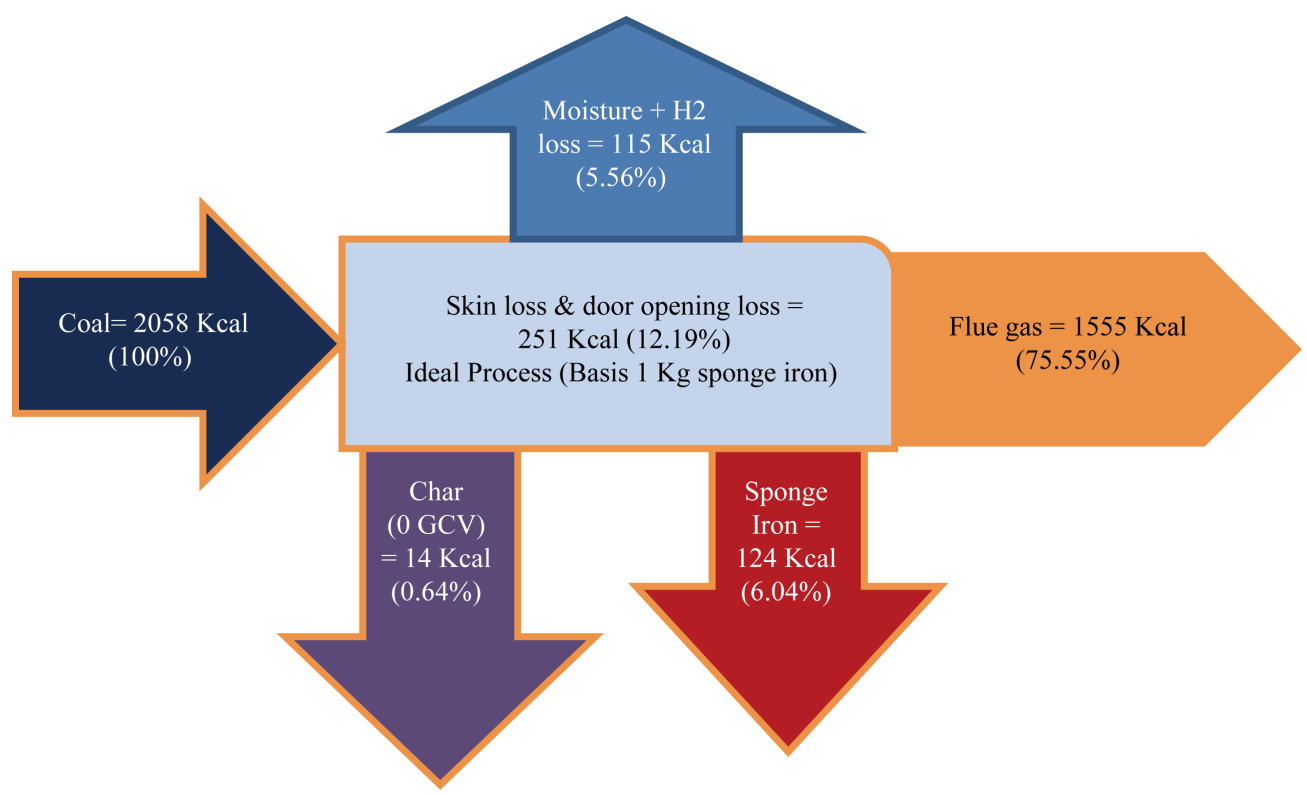

Figure 3. Sankey diagram of ideal kiln.

Table 5. Actual mass balance based on plant data.

\begin{tabular}{cccc}
\hline Iron ore & $1.55 \mathrm{Kg}$ & Sponge Iron & $1 \mathrm{Kg}($ Basis $)$ \\
Coal & $0.947 \mathrm{Kg}$ & Char input $=3889.84 \mathrm{Kcal}$ & $0.43 \mathrm{Kg}$ (calculated from mass balance) \\
Air & $3.28 \mathrm{Kg}$ & Flue gas & $4.41 \mathrm{Kg}$ (calculated from mass balance) \\
Dolomite & $0.068 \mathrm{Kg}$ & & \\
\hline
\end{tabular}




\section{Comparison of Theoretical Mass Balance vs. Actual Mass Balance \& Its Result}

- Instead of 1.43 , consumption of ore is 1.55 i.e. $8.4 \%$ higher than the stoichiometric ratio. This implies that the ore contains $8.4 \%$ impurity which finally comes out with char.

- Similarly coal consumption is 0.947 instead of 0.64 i.e. $48 \%$ higher than the theoretical requirement. The extra amount $0.947-0.64=0.307 \mathrm{Kg}$ is used as fuel to supply the heat required to make up additional losses.

- The reductant part of coal (0.64 Kg) generates $2058.12 \mathrm{Kcal}$ and the fuel part (0.307 Kg) releases 1831.72 Kcal of heat considering the said coal property.

- Therefore total heat supplied to the kiln in the process of making $1 \mathrm{Kg}$ sponge iron is $3889.84 \mathrm{Kcal}$.

- We have already seen that theoretical heat supplied to the kiln to produce $1 \mathrm{Kg}$ of sponge iron is 2058.12 Kcal.

- Therefore, Thermal efficiency of the Kiln is 2058.12/3889.84 $=52.91 \%$.

- So where the remaining $47 \%$ heat has gone?

- This can be found out by doing the actual heat balance of the kiln which is given below (Figure 4).

\section{Interpretation of Actual Heat Balance}

1) To produce 13.9 ton of sponge iron, 8.897 tons of coal are used as reducing agent which contributes to 28.61 MKcal of heat. 4.28 tons of coal used as fuel which releases $25.47 \mathrm{MKcal}$ of heat. Total heat input to the kiln per hour is 54.07 MKcal.

2) Heat loss thru flue gas is much less (36.24\% only) compared to theoretical one and value wise it is 19.60 $\mathrm{MKcal} / \mathrm{hr}$ only. All sponge iron plants have waste heat recovery boilers which utilize the waste heat of flue gas to produce steam and subsequently run a turbine. The power produced by this waste heat is sufficient enough to take care of the entire electrical load of the plant. Hence in true sense the entire process is thermal energy driven and to make effect to the energy baseline coal consumption must be reduced.

3) In this manufacturing process the products (sponge iron + char) are generated at high temp (around $1000^{\circ} \mathrm{C}$ ) and they need to be cooled below $100^{\circ} \mathrm{C}$ before they are sent to subsequent handling processes. So a common

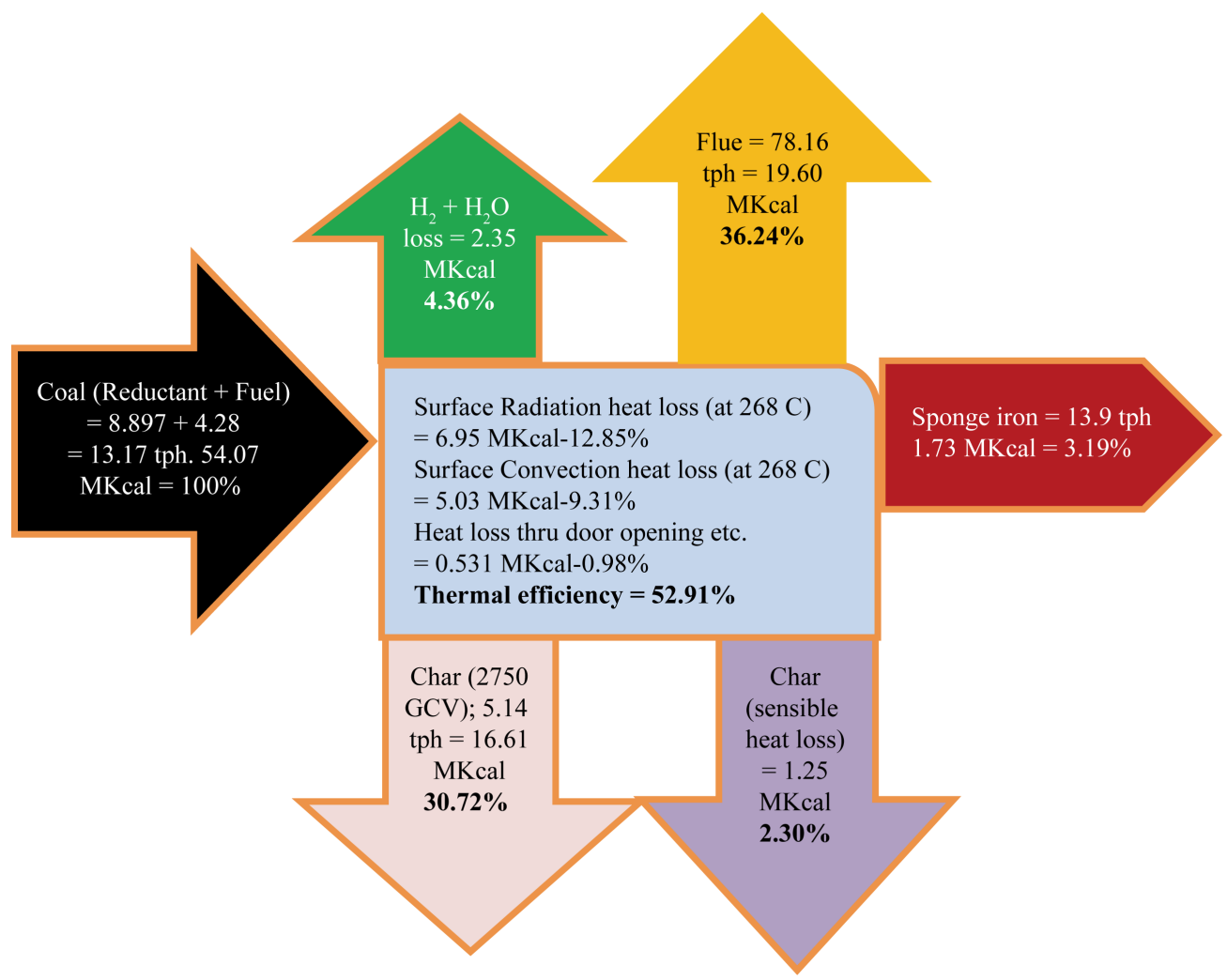

Figure 4. Sankey diagram of actual kiln of the plant. 
notion prevails in the plant that the cooling load costs lot of money and some steps to be taken to recover some portion of heat from the hot material. However the above heat balance shows that cooling load is only 5.509 $\mathrm{MKcal} / \mathrm{hr}$ or $10 \%$ of the total heat input.

4) On contrary, two major heat loss areas are most often overlooked by the plant people-loss of fixed carbon thru char and skin loss due to high surface temp of the kiln.

5) High percentage of fixed carbon (35\%) is found in char. Fixed carbon is the major contributor of heat in coal. Loss of fixed carbon leads higher demand of coal in the process. This loss is $30.72 \%$ or $16.61 \mathrm{MKcal} / \mathrm{hr}$.

6) Similarly skin loss (which is the combination of radiation \& convection loss) is $11.99 \mathrm{MKcal} / \mathrm{hr}$ or $22.17 \%$.

7) These two losses put together is around $53 \%$ of the total heat input.

\section{Conclusions}

1) The theoretical mass and heat balance tables are not universal as they get changed with the property of coal used. Hence energy auditors are advised to build individual tables for each case based on coal proximate analysis.

2) Type of coal and fixed carbon loss has a direct bearing on the kiln thermal efficiency. Where fixed carbon loss is high, plants may think of using low-grade coal (lower \% of fixed carbon) which comes at a cheaper rate. This step shall reduce their annual coal purchase bill.

3) We have seen plant which is using F grade coal (fixed carbon $24.19 \%$ \& GCV $2903 \mathrm{Kcal} / \mathrm{Kg}$ ) is getting very good Kiln efficiency $81 \%$ to $90 \%$ [2]. The main reason is that fixed carbon loss thru char is much less in this case. The GCV of char in this case is 850 to $1020 \mathrm{Kcal} / \mathrm{Kg}$ compared to 2750 in the earlier case.

4) We have seen some sponge iron companies trying to reduce radiation loss by applying low-emissivity reversible paint which brings down the emissivity level from 0.95 to 0.65 . But study shows that ultimately this becomes counter-productive. Application of coating although reduces the radiation loss but at the same time it enhances the surface temperature which in turn increases the convection loss.

5) Last but not the least, sponge iron companies should collaborate with "Catalyst" manufacturing companies to develop suitable catalyst for DRI process. The role of catalyst is to generate better reaction co-efficient which will ensure maximum consumption of fixed carbon of the coal.

\section{References}

[1] Choudhury, A. (2014) Energy Audit Report of Tata Sponge Iron Company Limited.

[2] Choudhury, A. (2014) Energy Audit Report of Mahendra Sponge \& Power Limited.

[3] Rakshit, P.C. Thermodynamics. Publisher, publisher's location.

[4] Hougen, O.A., Watson, K.M. and Ragatz, R.A. (1954) Chemical Process Principal. John Wiley \& Sons Inc., Hoboken.

\section{Abbreviations}

TOE $=$ Tons of oil equivalent

SEC = Specific energy consumption (annual energy consumption in toe/annual production of finished product in ton)

$\mathrm{GCV}=$ Gross calorific value $(\mathrm{Kcal} / \mathrm{Kg})$

$\mathrm{TPH}=$ Tons per hour

MKcal $=$ Million kilo calorie 
Scientific Research Publishing (SCIRP) is one of the largest Open Access journal publishers. It is currently publishing more than 200 open access, online, peer-reviewed journals covering a wide range of academic disciplines. SCIRP serves the worldwide academic communities and contributes to the progress and application of science with its publication.

Other selected journals from SCIRP are listed as below. Submit your manuscript to us via either submit@scirp.org or Online Submission Portal.
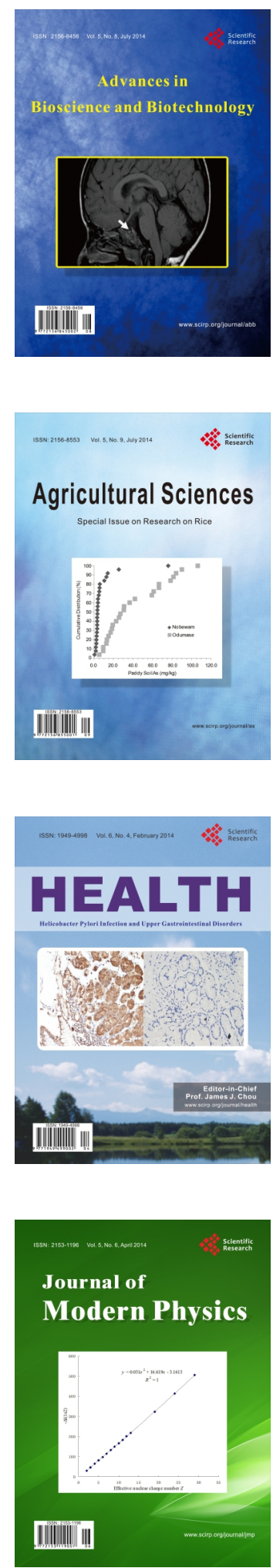
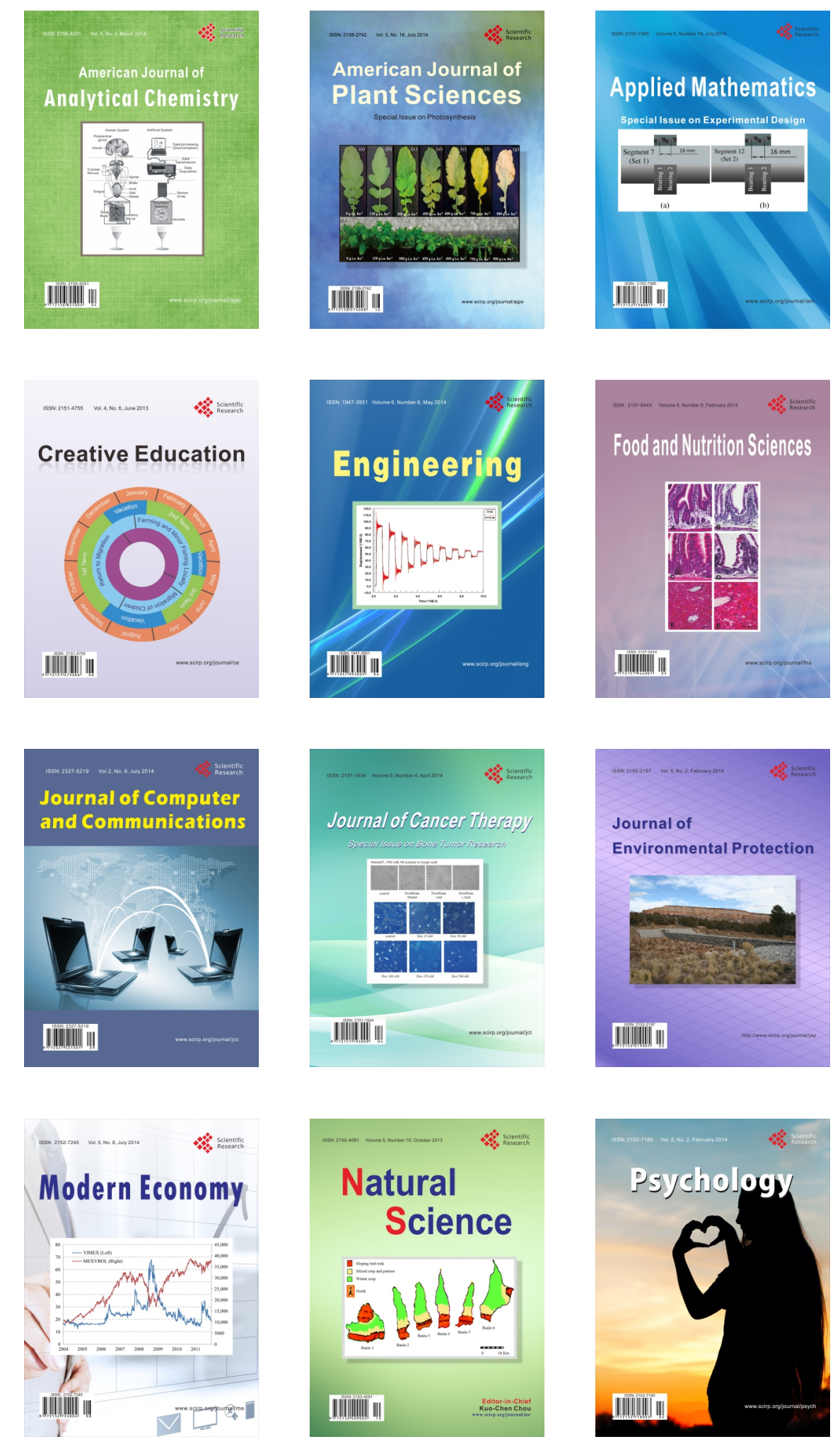